\title{
Fragments of Boethius: the reconstruction of the Cotton manuscript of the Alfredian text
}

\author{
SUSAN IRVINE
}

'These fragments I have shored against my ruins': T. S. Eliot's metaphor in The Waste Land evokes the evanescent frailty of human existence and worldly endeavour with a poignancy that the Anglo-Saxons would surely have appreciated. Such a concept lies at the heart of Boethius's De consolatione Philosophiae, and perhaps prompted King Alfred to include this work amongst those which he considered most necessary for all men to know. ${ }^{1}$ Written in the early sixth century, Boethius's work was translated from Latin into Old English at the end of the ninth century, possibly by Alfred himself. ${ }^{2}$ It survives in two versions, one in prose (probably composed first) and the other in prose and verse, containing versifications of Boethius's Latin metres which had originally been rendered as Old English prose. It is the latter of these versions which will be the focus of my discussion here. Damaged beyond repair by fire and water, the set of fragments which contains this copy will be seen to epitomize the ideas imparted by the work in ways that Alfred could never have envisaged.

The only extant copy of the alternating verse and prose version of the Old English Boethius is in a mid-tenth-century manuscript, London, British Library, Cotton Otho A. VI. The parlous condition of the manuscript can be directly attributed to the fire of 1731 that damaged or destroyed so many of the manuscripts and books collected by Sir Robert Cotton and later presented to the British people by his grandson in $1700 .{ }^{3}$ When the fire swept through Ashburnham House where the collection was being stored, enormous damage was inflicted not only by the flames themselves but also by the water used to douse them. The fragments of Otho A. VI which survived the inferno preserve a verse and prose version of the Old English Boethius not otherwise recorded.

Fortunately, attempts to reconstruct the contents of this version are not reliant solely on the often tantalizingly obscure evidence offered by these

1 See Alfred's Preface to his translation of Gregory's Cura pastoralis, in King Alfred's West-Saxon Version of Gregory's Pastoral Care, ed. H. Sweet, EETS os 45 (1934), 6-7.

2 Although Alfred did not necessarily himself translate Boethius's work, he is assumed to be the author for the purposes of this discussion.

3 On the development of the Cotton collection, see C. G. C. Tite, 'The Manuscript Library of Sir Robert Cotton', The Panizzi Lectures 1993 (London, 1994). 


\section{Susan Irvine}

fragments. First, the prose version of the work, extant in a twelfth-century copy in Oxford, Bodleian Library, Bodley 180, corresponds closely for much of its text with the Cotton version. The relationship between the two texts in those parts where the Cotton manuscript is still available suggests that the Bodley version reflects accurately the prose portions of the Cotton version. Reconstructing the contents of the Cotton version is also greatly facilitated by the existence of a seventeenth-century transcript made by the Dutch scholar Franciscus Junius (Oxford, Bodleian Library, Junius 12). He transcribed the Bodley manuscript and then collated it with the Cotton version, using the margins of his transcript of the Bodley prose version to collate the distinctive readings in the prose parts of the Cotton version, and using separate pieces of paper (now pasted in) to copy out the verse unique to the Cotton version. ${ }^{4}$ Clearly both the Bodley version and the Junius transcript are important witnesses to the text of the Cotton version where it is either lost or illegible.

The set of fragments which constitute what is left of Otho A. VI was subjected, along with other damaged Cotton manuscripts, to a painstaking process of restoration and reconstruction in the first half of the nineteenth century. ${ }^{5}$ Retrieved in the late 1820s from the so-called 'charter garret' where they had been stored, pages were soaked in a chemical solution of water and spirits of zinc to make them more pliable, and their edges were slit to help them lie flat. This practice, as the benefit of hindsight reveals, exacerbated the deterioration of the fragments: text was washed away by the soaking in the solution and the incisions in the pages resulted in what Andrew Prescott describes as the 'serrated' appearance of the leaves. ${ }^{6}$ It did, however, lead to the exciting rediscovery of a number of manuscripts hitherto assumed to have been lost or useless, amongst which was Otho A. VI.? Listed in around 1827 as one of the 'Saxon MSS. wanting' by Josiah Forshall, then Keeper of Manuscripts at the British Museum, ${ }^{8}$ Otho A. VI is recorded in a later list (compiled, again by Forshall, in

${ }^{4}$ On Junius's transcript, see further K. S. Kiernan, 'Alfred the Great's Burnt Boethius', The Iconic Page in Manuscript, Print, and Digital Culture, ed. G. Bornstein and T. Tinkle (Michigan, 1998), pp. 7-32, at pp. 8-14.

5 A. Prescott, "'Their Present Miserable State of Cremation": the Restoration of the Cotton Library', Sir Robert Cotton as Collector: Essays on an Early Stuart Courtier and his Legacy, ed. C. J. Wright (London, 1997), pp. 391-454. See also S. Keynes, 'The Reconstruction of a Burnt Cottonian Manuscript: the Case of Cotton MS. Otho A. I', Brit. Lib. Jnl 22 (1996), 113-60, and Edward Miller, That Noble Cabinet: a History of the British Museum (London, 1973), pp. 35[-6], n. $2 . \quad{ }^{6}$ Ibid. p. $406 .{ }^{7}$ Ibid. p. 405.

8 London, British Library, Add. 62576, 52r. In Appendix 2 of " "Their Present Miserable State", (pp. 439-40), Prescott lists in chronological order the contents of BL, Add. 62576 concerning the restoration of the damaged Cotton manuscripts. 


\section{Fragments of Boethius}

1830-2) as 'much damaged, but now being restored'. 'Following the completion of this stage of its restoration, Otho A. VI was apparently put into a case for safe keeping: in a table recording the condition of the damaged vellum Cotton manuscripts by Sir Frederick Madden (who took over as Keeper of Manuscripts in 1837), the 'Actual State [in] 1841' of Otho A. VI is described as ' 125 leaves in a case'. ${ }^{10}$

The restoration of the damaged Cotton manuscripts entered a new phase in the early 1840s when Madden collaborated with Henry Gough on the physical reconstruction of some of those considered to be the most important. Otho A. VI was restored by Gough in $1842-3 .{ }^{11}$ The elaborate process by which each leaf (or fragment thereof) was carefully inlaid by Gough in heavy paper frames using a combination of paste and tape has been described by Kevin Kiernan. ${ }^{12}$ Preceding Gough's inlaying, however, was the laborious task of identifying and arranging the fragments, a task which Madden himself apparently undertook. ${ }^{13}$ At this intervening stage when the fragments were being laid out and sorted in preparation for inlaying, they must have looked in some places more like a partially solved jigsaw puzzle than a manuscript.

Although Otho A. VI has clearly come a long way from the manuscript which was originally written in the mid-tenth century, its reconstructed form allows it now to be consulted and handled like any other medieval manuscript.

9 BL, Add. 62576, fol. 4. For the 1830-2 dating of this list, see Prescott, “"Their Present Miserable State"', nn. 119 and 123. The entry relating to Otho A. VI has been updated, probably on two separate occasions. The entry first read: 'Much damaged, but now being restored: Boethius'. To this was later added (on a new line): 'and arranged by Mr Holmes'. At a later stage again (either in or after 1832 when Madden was knighted), 'Mr Holmes' was crossed out and replaced by 'Sir F. Madden'. $\quad{ }^{10}$ BL, Add. 62576, 61v.

11 Prescott, "Their Present Miserable State", p. 416. Its completion in 1843 is recorded in BL, Add. 62576 at 61v, 42r and 51r. In London, British Library, Add. 62577, a 'List of the Cottonian MSS. with the Progress made in repairing, binding and inlaying of the Collections from the year 1839' (1r), Otho A. VI is recorded on 18v-19r as being 'inlaid and rebound' by 'G' (for Gough) in July 1844 (where 1844 has been altered from 1843). Prescott, "“Their Present Miserable State"', p. 426 and n. 251, notes that Gough was responsible only for the inlaying of volumes and not for their binding, which was done by the Museum's binder Charles Tuckett. $\quad{ }^{12}$ Kiernan, 'Alfred the Great's Burnt Boethius', pp. 15-16.

13 Prescott, "'Their Present Miserable State", pp. 414-16. John Holmes may have worked briefly on arranging the fragments of Otho A. VI in the early 1830s (see above n. 9), and there is anecdotal evidence that Joseph Stevenson, who worked at the British Museum from 1831 to 1834, may also have done so: see King Alfred's Anglo-Saxon Version of Boethius De Consolatione Philosophiae, ed. S. Fox (London, 1864), Preface, p. iii. It is reasonable to assume, however, that Madden was responsible for the final arrangement. On the collaboration of Gough and Madden, see also K. Kiernan, 'Odd Couples in Ælfric's Julian and Basilissa in British Library Cotton MS Otho B. X', Beatus vir: Studies in Anglo-Saxon and Old Norse Manuscripts in Memory of Phillip Pulsiano, ed. K. Wolf and A. N. Doane (Tempe, AZ, 2005, forthcoming), kindly made available to me prior to publication. 


\section{Susan Irvine}

One of the problems of such a skilful reconstruction is that of over-reliance on the final product, indeed of treating the reconstruction almost as if it were the manuscript itself. The fixed nature of its restored condition leads one to treat it as more authoritative than it actually is. This opens up unexpected pitfalls for modern editors in their attempts to present and interpret the text of the manuscript.

One way in which the fixed nature of the reconstructed manuscript has prompted misconceptions relates to the framing method. Until quite recently it has not unreasonably been assumed that what is visible in the manuscript is all that exists. This is not in fact the case. The method of restoration by which the damaged leaves are pasted on to retaining edges on the paper frames means that these retaining edges hide small amounts of text at the edges of the folio leaf on the verso side. As Kiernan has demonstrated, however, these tiny portions of texts are not irrecoverable. By reading the obscured vellum from behind with a cold fibre optic light source, Kiernan has shown that a number of the covered letters can be read. ${ }^{14}$ Kiernan's Electronic Boethius project is currently in the process of using a digital camera to record images of the obscured letters and by the process of computer imaging Kiernan aims to restore the hidden letters to their place in the manuscript. ${ }^{15}$

There is another way in which the fixed nature of the reconstructed manuscript has led to an unjustified assumption of its authority. Not only may modern readers be led to miss what is there since it is now hidden to the naked eye, but they may also be led to read what is not there. An important instance of this arises from two leaves of Otho A. VI, fols. 14 and 15.

Fols. 14 and 15 belong to the early part of the manuscript, which was the most severely damaged in the fire and was clearly in a particularly precarious condition. When these early leaves came to be sorted, the job of reassembling such a charred and misshapen pile of fragments must have seemed at times to verge on the impossible. In retrospect the level of accuracy achieved by Madden and any others who worked on fitting together the fragments is extraordinary. Mistakes, however, were made. Fol. 15 as it is currently assembled contains a portion of text which belongs elsewhere: a fragment of the manuscript has been incorporated into the wrong leaf altogether. Ultraviolet images of the relevant parts of the text make it possible to see details not visible under ordinary light. ${ }^{16} 15 \mathrm{r}(\mathrm{pl} . \mathrm{V})$ has a mosaic-like appearance which is not uncharacteristic of many of the manuscript's early folios. Variation in the

${ }^{14}$ Kiernan, 'Alfred the Great's Burnt Boetbius', pp. 18-19.

15 http://beowulf.engl.uky.edu/ kiernan/eBoethius/inlad.htm.

${ }^{16}$ I would like to thank Rosenkilde and Bagger for making available to me the originals of their ultraviolet photographs of the folios containing verse in Otho A. VI, which enabled this discovery; the photographs are reproduced in Old English Verse Texts From Many Sources: a 


\section{Fragments of Boethius}

texture of the vellum from one fragment to another is common, either because of the way the fire affected each one differently or because of varying restorative processes. In this case, however, one instance of variation in texture in the top half of the folio (the right hand portion of lines 7-10 of the extant text) turns out to be significant. Here, as the letters themselves attest, a fragment of the manuscript has been misplaced. ${ }^{17}$

The context here on $15 \mathrm{r}$ is a passage of prose in which Wisdom expresses satisfaction to Mod (as Alfred calls Boethius) that the teaching hitherto seems to be taking effect. The passage corresponds to one found on $15 \mathrm{v}$ of Bodley 180, which transcribes as:

Me pincð nu $\not$ wit mægen smealicor sprecan .7 diogol

ran wordū . for pam ic ongite $\bar{b}$ min lar hwæt hwugu

in gæð on pin ondgit. 7 pu genoh wel understenst $\vec{b}$ ic pe to

sprece. ${ }^{18}$

When we compare this passage to its counterpart in Otho A. VI, however, we do not find what we would expect to see in the text. As pl. V shows, the seventh line of $15 \mathrm{r}$ reads (from the margin) magen; this is followed after a gap by a letter that is probably $f$, which Madden may have assumed to be the $l$ of Bodley 180's subsequent word smealicor. The eighth line of $15 \mathrm{r}$ reads (from the margin) wordum; this is followed not by for, as we find in Bodley 180, but by letters which on close examination turn out to be rces. Madden apparently misread the $r$ as an $f$. The ninth line of $15 \mathrm{r}$ reads lar bwe; it is not followed then by the rest of the word bwathwugu, as it is in Bodley 180, but by the letters etta. These letters are probably the main reason for the placement of this fragment in its current position; Madden could presumably make out the et on the fragment and not much else, and this must have seemed to fit well with the preceding hwa , since probably only the first part of its $a$ was visible. It is in the tenth line of $15 \mathrm{r}$ that the misplacing is most evident: 7 pu geno, according to comparison with Bodley 180, should be the beginning of $7 \mathrm{pu}$ genoh wel, but instead it is followed by the crossed thorn abbreviation $(\mathfrak{b})$ and

Comprehensive Collection, ed. F. C. Robinson and E. G. Stanley, EEMF 23 (Copenhagen, 1991). I would also like to thank Kevin Kiernan for since making available to the Boethius Project his digital ultraviolet images of the manuscript.

17 Although my discussion here will focus on this particular fragment, it is by no means the only example of this kind of error in the reconstruction of the manuscript. Another example can be seen in a small fragment of what is now fol. 6, which properly belongs, I would suggest, with fol. 5: on 6r (line 9 of the surviving text), sie $p$ is followed by $i d$ bim, but this latter fragment of text would fit better after eac $m$ on $5 \mathrm{r}$ (line 1 of the surviving text).

18 'It seems to me that we can speak more searchingly and in more hidden words, because I perceive that my teaching to some extent penetrates your mind, and you understand clearly enough what I am saying to you.' (Translations are my own unless otherwise stated.) 


\section{Susan Irvine}

te (patte in its expanded form). Presumably in this case the crossed thorn was misread as the $w$ of wel. $^{19}$

Although, as we have seen, the shape of some of the letters visible on the recto side of the fragment made its present placement on $15 \mathrm{r}$ plausible, it is clearly erroneous. I will return later to the question of where this fragment properly belongs. Before doing so, however, I would like to consider its implications in relation to readers and editors. The misplacing of this fragment highlights one of the most problematic aspects of studying a manuscript like Otho A. VI. Sometimes, no matter how long and hard one stares at the text, or indeed perhaps because of how long and hard one stares at the text, it is impossible to decide whether a particular reading is visible or not. Given that Bodley 180 presents corresponding material for comparison with the prose passages in Otho A. VI, and that the Junius transcript offers a copy of the verse passages in Otho A. VI, the temptation to 'see' what ought to be there can be overwhelming. Madden presumably thought he could read letters which were not in fact there, but he is by no means alone in this. The tendency for the editorial mind to see what it wants to see is nowhere better exemplified than in the standard edition of the Old English Boetbius.

Sedgefield's edition of the Old English Boethius, published in 1899, has remained the standard one for over a century. ${ }^{20}$ Although Sedgefield presents the work as a whole in the all-prose, forty-two chapter structure of Bodley 180, his edition was innovative in making its primary copytext Otho A. VI. ${ }^{21}$ Sedgefield states that at the time he was working, about three-quarters of the whole manuscript remained and that most of it was legible, though some leaves could 'only be properly read in a good light', and for a few 'even direct sunlight' was necessary. ${ }^{22}$ Sedgefield describes in his Preface how 'individual pages of this MS. have received as much as an hour's scrutiny, and this scrutiny was repeated three or even four times in a few instances. By taking advantage of the rare intervals of London sunshine during the winter and spring months, I found much decipherable which in ordinary light would have remained hidden. ${ }^{23}$ It is true of course that, perhaps even as a result of the bright sunshine which Sedgefield called to his assistance in the 1890s, its text may be less

19 The verso side of the fragment shows more deterioration than the recto side. Some lettershapes which are partly visible do, however, point to a similar lack of correspondence with the equivalent text on 16r in Bodley 180.

${ }^{20}$ King Alfred's Old English Version of Boethius De Consolatione Philosophiae, ed. W. J. Sedgefield (Oxford, 1899).

21 Earlier editions based their text on Bodley 180, though they recorded variants drawn from Junius's transcript and, in the case of Fox's 1864 edition, some collations from Otho A. VI itself. For accounts of these earlier editions, see M. R. Godden, 'Editing and the Problem of Alfred's Boethius', The Editing of Old English: Papers from the 1990 Manchester Conference, ed. D. G. Scragg and P. E. Szarmach (Cambridge, 1994), pp. 163-76, and Kiernan, 'Alfred the Great's Burnt Boethius'. $\quad{ }^{22}$ King Alfred's Boethius, ed. Sedgefield, p. xii. $\quad{ }^{23}$ Ibid., p. vii. 


\section{Fragments of Boethius}

legible now than it was then. But Sedgefield's claim that he found most of the manuscript to be legible needs further scrutiny. The misplaced fragment on fol. 15 identified above provides a telling illustration of the dubious nature of this claim. The relevant passage on $15 \mathrm{r}$ is edited by Sedgefield as follows:

Me pinc $[n u]$ b wit mægen [smealicor sprecan 7 diogolran] wordum, for [pam ic ongite 5 min] lar hwæthwu[gu in gad on pin ondgit] 7 pu genoh wel [understenst 5 ic pe to] sprece. ${ }^{24}$

Sedgefield presents a cluttered-looking text with a plethora of italics and square brackets as well as ordinary type. His procedure here is to put all words in the text which are illegible in Otho A. VI into italics, and all words which are missing as a result of damage into both italics and square brackets. The words in italics are taken from the text of Bodley 180. The clear implication is that anything not in italics, whether in square brackets or not, was legible in Otho A. VI when Sedgefield was preparing his edition.

Sedgefield, however, cannot have read what he claims to have been able to read on $15 \mathrm{r}$ because some of the text he claims to have read does not in fact exist. In the excerpt above, neither wordum nor for-is italicized. As we have seen (pl. V), the word wordum is indeed in the text, but it is followed not by the letters for but rather by rces. Although Sedgefield must have thought he could read for because he expected to see for at this point, he could not have read these letters. His representation of hwethwngu is similarly misleading: Sedgefield must have thought he could read the letters thw in the middle of this word, but he could not actually have done so because the manuscript reads etta. Furthermore Sedgefield clearly thought he could read the whole of genoh; once again his over-active imagination was apparently at work, since although the letters geno are there the final $b$ is most definitely not.

This is a clear-cut case where Sedgefield seems to have thought he could see more than he actually could. ${ }^{25}$ But how large a part of his text is based on assumptions like this? In preparing a new edition of the Old English Boethius, one can never take Sedgefield's readings as indicative of how much more legible the manuscript was a century ago than it is now. ${ }^{26}$ Sedgefield was certainly more discriminating than Fox, who claimed in his 1864 edition that Otho A. VI 'is now rendered so perfect that most of it can be read with the greatest ease!', ${ }^{27}$ but who seems in fact to have consulted this manuscript rather rarely.

24 Ibid., p. 27, lines 15-18.

25 Although the illegibility of the same fragment on its verso side makes it difficult to draw definitive conclusions, it is likely that at least with the beginning of the word monnum, which is not italicized in his edition (King Alfred's Boethius, p. 28, line 5), Sedgefield is claiming to have read letters which are not in the manuscript.

26 A new edition is currently in preparation by Malcolm Godden and myself, as part of the Old English Boethius Project, generously funded by the Arts and Humanities Research Board of the United Kingdom. $\quad{ }_{27}$ King Alfred's Anglo-Saxon Version of Boethius, ed. Fox, p. iii. 


\section{Susan Irvine}

Fox may assert that in his edition 'every word contained in both MSS. is given, and the variations, which are the result of a careful collation, are marked at the foot of each page', ${ }^{28}$ but, as Sedgefield notes, Fox has in fact relied heavily on Christopher Rawlinson's 1698 edition (based on Junius's transcript), supplementing its readings with variants taken directly from Otho A. VI for only part of his text. ${ }^{29}$ Sedgefield, however, was probably relying more on the readings of Bodley 180 and of Junius's transcript than he was himself even aware. Presumably without realizing it, Sedgefield was constantly interpreting the manuscript as he edited it. A modern editor has to ensure that a new edition does not perpetuate Sedgefield's unwitting errors. In some cases, the result of modern technology will be to reveal that we can see less than Sedgefield claimed he could see, rather than more.

The misplaced fragment clearly has important implications for our understanding of earlier editorial practices. I wish to turn now to a different question arising from the fragment: if its present position is incorrect, then where should it have been placed? In considering this question, it seems a reasonable assumption that if the fragment does not belong in its current position, and cannot be made to fit anywhere else on fol. 15, then its home is most likely to be with one or other of the adjacent folios. This in fact turns out to be the case. Fol. 14 has some missing text which matches that on the misplaced fragment. The text is part of one of the metres of the Old English Boethius, Metre 7, which occupies the whole of $14 \mathrm{r}$ and $14 \mathrm{v}$, and the top of $15 \mathrm{r}$. The metres are not, of course, found in Bodley 180, which contains only the prose version of the work; parts of the metres missing or illegible in Otho A. VI are attested only by Junius's transcript. Identification of a portion of text, however fragmentary, which adds to manuscript evidence for the metres is particularly valuable, since Junius's transcript made before the manuscript was burnt cannot be assumed to be correct.

An illustration of folio 14 recto shows a gap at almost precisely the same point on the leaf as the point at which we find the fragment on $15 \mathrm{r}$ (pl.VI). As pl. VI shows, line 7 of $14 \mathrm{r}$ begins ne pe; the corresponding part of the fragment offers what is probably a $f$. Line 8 begins pas; the corresponding part of the fragment offers rces. Line 9 begins oferm; the corresponding part of the fragment offers etta. Line 10 begins pu afr , the corresponding part of the fragment offers (in its expanded form) patte. By looking at the relevant section of Junius's transcript we can see how these parts might have fitted together:

28 Ibid. p. iv.

${ }^{29}$ King Alfred's Boethius, ed. Sedgefield, p. xxii. For Rawlinson's edition, see An. Manl. Sever. Boethii Consolationis Philosophiae Libri V. Anglo-Saxonice redditi ab Alfredo, Inclyto Anglo-Saxonum Rege. Ad apographum Junianum expressos, ed. C. Rawlinson (Oxford, 1698). 


\section{Fragments of Boethius}

Ne ðearf eac hæleða nan . wenan pæs weorces . § he wisdom mæge . wið ofermetta . æfre gemengan; herdes pu æfre . łte ænig mon. on sondbeorgas . settan meahte . fæste healle? $?^{30}$

The ne pe in Otho A. VI corresponds to the beginning of what Junius transcribes as ne Jearf (with his characteristic confusion of $\partial$ and $b$ ), the $f$ of which is probably provided by the fragment. The word pas is followed in the transcript by weorces, the rees of which is supplied by the fragment. The letters oferm are the beginning of the word ofermetta in the transcript, and the fragment supplies etta. In the transcript pu afr is the beginning of pu afre patte, of which the fragment supplies the last word. The jigsaw piece slots in, not as neatly as one might hope in terms of shape, given the distortion caused by the fire and subsequent crumbling, but the fit in terms of text is perfect. Junius, it can now be confirmed, transcribed accurately the parts of the text available on the fragment. $^{31}$

The fragment supplies a small amount of text which has hitherto been assumed to have perished. The implications of this are clearer in the context of a printed version of the text. I cite here the relevant section of Metre 7 in the standard Anglo-Saxon Poetic Records edition (reproducing in this case its italics which show the text supplied from Junius's transcript):

\begin{tabular}{|c|c|}
\hline & Ne pearf eac haleða nan \\
\hline æs weorces, & pat he wisdom mage \\
\hline wið ofermetta & afre gemengan. \\
\hline Herdes pu æfre & patte anig mon \\
\hline $\begin{array}{l}\text { on sondbeorgas } \\
\text { faste healle? }\end{array}$ & $\begin{array}{l}\text { settan meabte } \\
(6-11)^{32}\end{array}$ \\
\hline
\end{tabular}

In lines 6-9, the discovery of the fragment means that italics are no longer necessary on the fof 'pearf', the rces of 'weorces', the tta of 'ofermetta', and 'patte'. In line 8 the second $e$ of 'ofermetta' should have been italicized by Krapp since this letter does not in fact exist on $14 \mathrm{r}$ in its current configuration, and is available only from the misplaced fragment. Once more we have an example of an editor

${ }^{30}$ Junius 12,14v: 'Moreover no man should think in respect of that matter that he can ever mix wisdom with pride. Have you ever heard of any man being able to set sturdy halls on mounds of sand?' Facsimile copies of Junius's transcriptions of the metres in Otho A. VI are included in Old English Verse Texts, ed. Robinson and Stanley; see 5.8.1.2 for the passage cited here.

31 Unfortunately, given the damage to the verso side of the fragment, it is not currently possible to be certain about Junius's transcription of that part of the text which is affected by the fragment's discovery (Old English Metre 7, lines 32-4, cited below).

32 The Paris Psalter and the Meters of Boethius, ed. G. P. Krapp, ASPR 5 (New York, 1932), 160: 'Moreover no man should think in respect of that matter that he can ever mix wisdom with pride. Have you ever heard of any man being able to set sturdy halls on mounds of sand?' 


\section{Susan Irvine}

who, like Sedgefield, has read what he expects to be there rather than what is actually there. ${ }^{33}$

The discovery of more manuscript evidence for the text of one of the Old English Boethius metres than was known to exist is for an editor exciting in itself. There is also, however, an ironic appropriateness which emerges from considering the literary context of this fragment of text, and it is this aspect which I wish to explore in the last part of this paper. The fragment, as has been seen, contains text which correctly belongs to Metre 7 of the Old English Boethius. This metre presents a loose translation of Book II metrum 4 of Boethius's De consolatione Philosophiae. In Boethius's Latin metre, Philosophia explains to Boethius how the wise man builds his house on a low and stable foundation, allowing him to live a calm existence despite the turmoil outside:

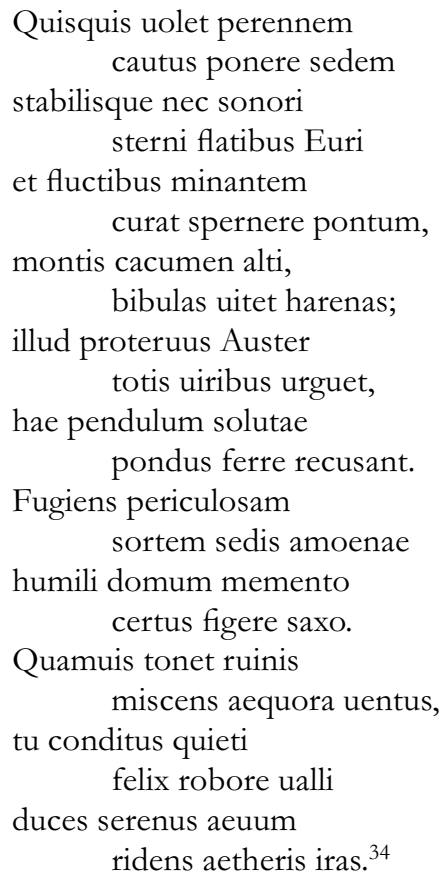

33 Krapp may here have been influenced by Sedgefield, who also claims to have been able to read the second $e$ of ofermetta in his edition of Metre 7 (King Alfred's Boethius, p. 159). The letter is correctly italicized in Alfred's Metres of Boethius, ed. B. Griffiths (Pinner, 1991), p. 65.

34 Anicii Manlii Senerini Boethii Philosophiae Consolatio, ed. L. Bieler, CCSL 94 (Turnhout, 1957), 25-6. Trans. S. J. Tester in Boethius The Theological Tractates [and] The Consolation of Philosophy, ed. J. F. Stewart, E. K. Rand and S. J. Tester (Cambridge, MA, 1978), p. 199: 'The prudent man/ Intending to build a house to last/ Stable, not to be tumbled down/ By the south-east wind with its noisy blast,/ Nor crumbled by the sea/ With its threatening waves,/ Will avoid the mountain top/ And the thirsty desert sand;/ The one is buffeted/ By all the force of the violent south wind;/ The other shifts/ And will not bear the heavy-hanging weight./ Run 


\section{Fragments of Boethius}

In its Old English version this short Latin metrum is expanded into a poem of fifty-four lines. The Old English metre, perhaps prompted by commentary material which points in the same direction, ${ }^{35}$ explains at some length the implications of Boethius's more allusive verse, explicitly linking the housebuilding image with a person's state of mind: if one is proud and covetous, one will be shaken by earthly troubles; if one is wise and humble, then one will be happy despite earthly adversities.

Early in the metre, Alfred warns that no man can build wisdom on a hill which is covered over with earthly greed:

Ne mæg eac fira nan

wisdom timbran pær ðær woruldgitsung

beorg oferbrædeð. $(11-13)^{36}$

Alfred typically combines concrete image and abstract idea: in the phrase wisdom timbran, the physical image of building is bound up linguistically with the spiritual concept of wisdom. ${ }^{37}$ Alfred expands this metaphor later in the metre:

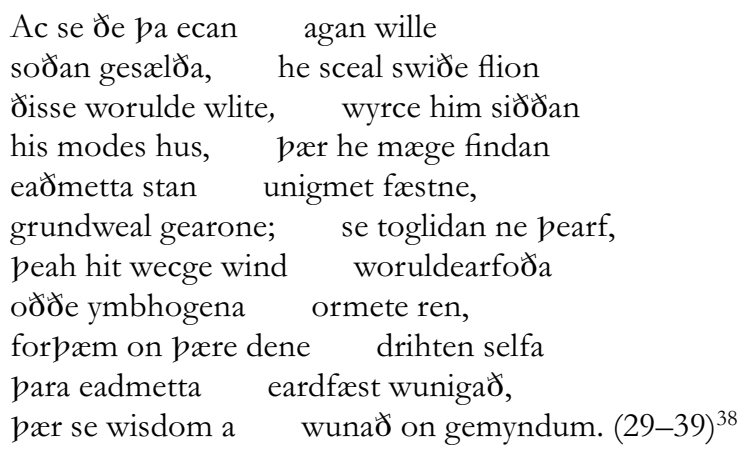

from the risks of a beautiful place/ That might be dangerous./ Be careful, certain; build your house/ On a low rock base./ Then though the wind thunder and make/ A ruinous turmoil of the troubled sea,/ You, safe settled and content/ Within your own strong walls,/ Will quietly live your life/ Smiling at all the anger of the skies.'

35 The commentary material is currently being collated as part of the Old English Boethius Project, and I am grateful to Malcolm Godden and Rohini Jayatilaka for making available to me the relevant section.

${ }^{36}$ The Paris Psalter and the Meters of Boethius, ed. Krapp, p. 160: 'Nor indeed can any man build wisdom where covetousness is spread over the hill.'

37 One might compare the phrase timbran eaðmodnesse in the Old English translation of Gregory's Cura pastoralis; see King Alfred's West-Saxon Version of Gregory's Pastoral Care, ed. Sweet, p. 443, line 30.

38 The Paris Psalter and the Meters of Boethius, ed. Krapp, p. 161: 'But he who seeks lasting true delights must indeed shun this world's beauty; afterwards let him construct the house of his mind where he can find the rock of humility, extremely sturdy, a stable foundation. It has no cause to collapse though the wind of worldly troubles or the flood of anxieties should afflict it; for in that valley of humility lives the Lord Himself, settled in His home, and there wisdom always dwells in men's minds.' 


\section{Susan Irvine}

Extending considerably his Boethian source - bumili domum memento / certus figere saxo (lines 15-16) - Alfred explains that to achieve true happiness, one must construct a house of one's mind where one can find the rock of humility and with it wisdom.

What exactly does Alfred have in mind when he urges his audience to 'build wisdom', and to 'construct a house of one's mind'? The metaphor of housebuilding is used elsewhere by Alfred, in his Preface to his translation of Augustine's Soliloquia, and this offers a productive parallel to its use in the Old English Boethius. In this passage, Alfred uses the metaphor of gathering wood to build a house to describe his own assimilation of ideas from a variety of literary sources:

Gaderode me ponne kigclas and stupansceaftas, and lohsceaftas and hylfa to ælcum para tola pe ic mid wircan cuðe, and bohtimbru and bolttimbru, and, to ælcum para weorca pe ic wyrcan cuðe, pa wlitegostan treowo be pam dele ðe ic aberan meihte. ne com ic naper mid anre byrðene ham pe me ne lyste ealne pane wude ham brengan, gif ic hyne ealne aberan meihte; on ælcum treowo ic geseah hwæthwugu pæs pe ic æt ham beporfte. ${ }^{39}$

The image of house-building here, as Alfred himself makes clear later in the Preface, is used to denote the acquisition of wisdom from the patristic fathers such as Augustine and Gregory. By gathering understanding from books, one will be able to live more calmly in this world and also be more prepared for the next. In his image of transporting the timbers Alfred may also have had in mind his own literary endeavours in translating books; in a different Preface, that to his translation of Gregory's Cura pastoralis, Alfred argues that both wisdom and the wealth obtained through it have been lost because people would not apply themselves to acquiring the understanding offered by texts. Through the process of translation, as he explains, he seeks to make the books which he regards as 'niedbeðearfosta . . . eallum monnum to wiotonne' available to a much wider audience. ${ }^{40}$

When in Metre 7, therefore, Alfred advocates building wisdom, he presumably has in mind the texts from which such wisdom can be attained, including the one which he is in the process of translating. The house of one's mind is

39 King Alfred's Version of St Augustine's Soliloquies, ed. T. A. Carnicelli (Cambridge, MA, 1969), p. 47. Trans. S. Keynes and M. Lapidge, Alfred the Great (Penguin, 1983), p. 138: 'I then gathered for myself staves and props and tie-shafts, and handles for each of the tools that I knew how to work with, and cross-bars and beams, and, for each of the structures which I knew how to build, the finest timbers I could carry. I never came away with a single load without wishing to bring home the whole of the forest, if I could have carried it all - in every tree I saw something for which I had a need at home.'

${ }^{40}$ King Alfred's West-Saxon Version of Gregory's Pastoral Care, ed. Sweet, p. 7: 'most necessary for all men to know'. 


\section{Fragments of Boethius}

built through acquiring ideas from works such as these. Finding the rock of humility, the sure foundation which can withstand the buffeting of earthly troubles, the dwelling-place of God and wisdom, depends on the existence of texts which provide the necessary knowledge in an earthly form.

Paradoxically, however, the book itself is an emblem of earthly mutability. Alfred's own recognition of this is evident in his Preface to the translation of Gregory's Cura pastoralis, when he recalls how he saw 'ærðæmðe hit eall forhergod wære \& forbærned, hu đa ciricean giond eall Angelcynn stodon maðma \& boca gefyldæ'. ${ }^{41}$ Books, like treasures, are perishable. At the same time as Alfred argues for the essential role of books in man's pursuit of wisdom, he recognizes the inherently ephemeral nature of these books as physical objects.

It is this paradox that creates the ironic appropriateness in the manuscript context of the misplaced fragment of text. Even as Metre 7 itself focuses on the need to build wisdom to counter earthly adversity, the manuscript leaves on which it is recorded poignantly exemplify the fragility of the books by which Alfred believes such wisdom can be acquired. These leaves, fols. 14 and 15, damaged terribly by fire and water in the eighteenth century and subjected to a process of fallible reconstruction in the nineteenth century, epitomize the volatile and unreliable nature of the manuscript text. Ultimately, it seems, the manuscript itself is more appropriately linked with the precarious position of earthly halls on high hills which Alfred describes near the beginning of Metre 7:

$$
\begin{aligned}
& \text { cwæð pæt he ne herde pæt on heane munt } \\
& \text { monna ænig meahte asettan } \\
& \text { healle hroffæste. }(3-5)^{42}
\end{aligned}
$$

Like the ruined hall without a firm roof, the Cotton manuscript itself exemplifies the danger of setting one's store by earthly goods as opposed to spiritual ones. Alfred in Metre 7 muses on the stability which can be attained by building wisdom, at the very point where the text itself is for modern readers at its most unstable. ${ }^{43}$

41 Ibid. p. 5: 'before it was all ravaged and burnt up, how the churches throughout all England stood filled with treasures and books'.

42 The Paris Psalter and the Meters of Boethius, ed. Krapp, p. 160: '[Wisdom] said that he had never heard of anyone being able to erect a hall with a firm roof on a high mountain'.

43 I would like to thank Malcolm Godden, Rohini Jayatilaka, Kevin Kiernan and Henry Woudhuysen, for their comments on an earlier version of this paper. 